Original Research Paper

\title{
How to Apply CxG to Phraseology: A Multilingual Research Project
}

\author{
${ }^{1}$ Valentina Benigni, ${ }^{2}$ Paola Cotta Ramusino, ${ }^{2}$ Fabio Mollica and ${ }^{3}$ Elmar Schafroth \\ ${ }^{I}$ Dipartimento di Lingue, Letterature e Culture Straniere, Università degli Studi di Roma TRE, Rome, Italy \\ ${ }^{2}$ Dipartimento di Scienze della Mediazione Linguistica e di Studi Interculturali, Università degli Studi di Milano, Milan, Italy \\ ${ }^{3}$ Institut für Romanistik, Heinrich-Heine-Universität, Düsseldorf, Germany
}

Article history

Received: 02-02-2015

Revised: 08-05-2015

Accepted: 08-05-2015

Corresponding Author:

Fabio Mollica

Dipartimento di Scienze della

Mediazione Linguistica e di Studi

Interculturali, Università degli

Studi di Milano, Milan, Italy

Email: fabio.mollica@unimi.it

\begin{abstract}
In the present research project, we will set out to design and populate a multilingual database which lists and describes Italian, Chinese, English, French, German, Japanese, Russian and Spanish phraseologisms. We firmly believe that the multilingual database will prove particularly useful in second language teaching. We will endorse the holistic perspective of Construction Grammar as our theoretical and applied framework (Goldberg, 1995; Croft, 2001): we conceive of phraseologisms, in particular idiomatic expressions, as 'constructions', i.e., form-meaning pairings whose meaning is not compositional. With reference to Croft (2001), we will describe multi-word units in their phonological, morpho-syntactic, semantico-pragmatic and discursive aspects (Schafroth, 2013) with the aim of providing an updated tool for second language acquisition and teaching purposes.
\end{abstract}

Keywords: Construction Grammar, Phraseology, Idioms, Multilingual, Database, FRAME

\section{Introduction}

Idiosyncrasy in the sense of non-predictability is the normal case in a language and it is to a large extent language specific. This can be a matter of single words, comprising meanings that are not inherent to a comparable word in another language with which it shares at least one meaning (for example, the two nouns plate in English and piatto in Italian). Moreover, idiosyncrasy is particularly relevant when we deal with multi-word linguistic patterns. As we generally do not speak in single words but in larger syntagmatic units, with many of these units being more or less entrenched or idiomatic (non-compositional) word combinations both characteristics, idiomatic and entrenched, representing idiosyncrasy - we may understand how difficult it is to have a good command of a foreign language. Although we are not aware of idiosyncrasy in our own language, we realize at a very early stage of our foreign language learning that idiosyncrasy and nonpredictability are everywhere. We can take almost nothing for granted when we embark on the adventure of learning a new language.
To support this argument, it is not even necessary to refer to linguistic patterns like to spill the beans or red herring. The problems foreign learners generally have concern the entire use of the language. Let us consider some examples: the German expression sich in den Finger schneiden (lit. 'to cut into the finger'), corresponds in English to cut one's finger and in Italian to tagliarsi il dito. If you absolutely do not want something to happen you can say (You will marry him) over my dead body! In German you would say (Du heiratest ihn) nur über meine Leiche! Even if there is correspondence between the concepts involved (Leiche 'dead body') it is the little things that cause big problems, i.e., the innocuous word nur in German and the adjective dead in dead body (body, in fact, also means 'dead person'). If we look at Italian, the analogous construction is fairly different, containing a modal verb (dovere), a verb (passare) and an optional temporal adverb (prima): Dovrai (dovrete, dovranno) (prima) passare sul mio cadavere! Franz Josef Hausmann was generally correct when he painted a rather bleak picture of the lexical and phraseological similarities between two languages: 
[D]ans une langue étrangère presque tout est différent, presque tout est idiomatique. C'est le parallélisme qui est l'exception, non la spécificité (Hausmann, 1997: 284).

Is Hausmann exaggerating? With regard to the great amount of non-corresponding collocations and set phrases in two languages (including phrasetemplates and formulas), one is inclined to say that the answer is "No". We must instead admit that: "[1]e lexique n'est pas compositionnel, il est idiomatique" (288) and that: "le fait idiomatique [...] est au centre de la langue, non à sa périphérie" (289). But how can we manage to get our foot in the door of multilingual learner-centred phraseology? If we want to tackle this problem we should first present our goal and then the methods we want to use in order to achieve it. This is the topic of the present article.

The objective of any learner-appropriate approach to a multilingual phraseology project must be to create a methodological tertium comparationis. In terms of phraseology, this basis for comparison can only be premised on concepts and not on forms. The comparability of phraseologisms (for a definition see below) in different languages can only be achieved by an onomasiological approach. Starting form a conceptual structure represents a sensible strategy to ensure that neither semantic nor pragmatic features disturb the crosslinguistic comparison on its basic level. Fundamental concepts of human life, such as politeness, greeting, thanking, complaining, asking, refusing are, mutatis mutandis, universal, taking of course into methodological consideration particular cultural and societal conditions (such as Japanese hierarchy-based communication, for instance). This assertion leads naturally to a multi-lingual perspective that first determines whether or not a given concept (for example, 'greeting an unknown person in the afternoon') is directly achieved in a language (e.g., English Good afternoon, Spanish ;Buenas tardes!) or whether it has no direct equivalent and the expression in question is used for a longer period of time than just the afternoon (French Bonjour!, German Guten Tag, Russian Dobryj den'!). Secondly, we have to add descriptors that are suitable for specifying the semantic, pragmatic and discourse-functional features of the form in question in one language or the other. These descriptors might be hierarchical or communicative constraints of any kind, regional particularities, markedness in register or style, etc. In Italian we could give Buona sera! as an approximative equivalent, but we would have to specify that it is regionally marked.

What we have in mind in our project is a multifunctional database structured in a way that phraseologisms can be queried in eight languages by concepts organized in semantic fields (according to the onomasiological approach set up for French by Bárdosi et al., 2003). In concordance with the European Reference Framework, the phraseologisms of each language could furthermore be classified in levels A to $\mathrm{C}$, depending on the complexity of form, meaning and usage (this is what we are planning to do at a later stage). We are aware that we are breaking new ground when we combine phraseology (in a broad sense) with cognitive aspects (i.e., their conceptual classification) on the one hand and learner-specific levels on the other, providing linguistic data for languages that have not yet been compared in such a way.

Additionally, all the phraseologisms recorded in this database will be described as comprehensively as possible. As far as our theoretical framework is concerned, our project is based on Construction Grammar (hereafter $\mathrm{CxG}$ ). Phraseology has far too long been neglected or excluded by reductionist grammars whose theoretical premise is to explain language as a set of separate modules and rules. ${ }^{1}$ By contrast, $\mathrm{CxG}$, which will be discussed in greater depth below, focuses on the idea of language as a continuum between lexicon and grammar, which would represent distinct components in other grammatical theories. The basic defining characteristics of a construction form the theoretical foundation for our project. If we agree that constructions are "learned pairings of form with semantic and discourse function" (Goldberg, 2006: 215) and that "some aspect of [their] form or function is not strictly predictable from [their] component parts or from other constructions" (ibid.: 5), then we have to tell our learners what it is that makes linguistic patterns such as German bei weitem, English by far and Italian di gran lunga idiosyncratic (and thus constructions). Similarly we must explain why phrases like Italian e scusa se è poco (lit. 'and sorry, if it is a little'), hai voglia! (lit. 'you have desire!') or si chiama Pietro ('his name is Peter') are "entrenched routine" (Croft, 2005: 274). And we have to describe these patterns as exactly and comprehensively as we can, taking a close look at language use as it is documented in linguistic corpora, from where we borrow our examples. Translating these theoretical foundations into a database will be the task of the international project called FRAME (FRAseologia Multilingue Elettronica) (see below). Even if we adopt Croft's radical point of view about $\mathrm{CxG}$, according to which "there are no universal constructions" and "all constructions are language specific [...]" (ibid.: 277), it is all the more necessary

\footnotetext{
1 "A reductionist theory begins with the smallest units and defines the larger or more complex units in terms of combinations of atomic units. All contemporary theories of syntactic representation are reductionist" (Croft, 2005: 283).
} 
to describe all the construction-specific and languagespecific properties in a way which allows learners to understand and even use these phraseologisms.

\section{Phraseological Studies: State of the Art}

Phraseologisms, understood here as complex lexical constructions of more than one word, which designate conceptual units, have been studied in the literature under various names - among which idioms and phrasemes (Burger, 2010; Donalies, 2009; Fleischer, 1997; Makkai, 1972; Mel'čuk, 1998) - and according to different theoretical approaches, in particular starting from their (often non-compositional) semantics.

As early as the start of the last century, Bally (1951 [1909]), editor of Saussure's Cours, had introduced the notion of locutions phraséologiques, which contained the category of the unités phraséologiques to indicate fixed word combinations of words characterized by a high internal cohesion, both structural and semantic.

This topic was particularly developed in Soviet linguistics, where the phraseological units were studied above all from a structural point of view, in opposition to the fixed word combinations, under the generic label of ustojčivye slovosočetanija 'fixed word-combinations'.

Vinogradov can be considered the father of this area of study; borrowing from Bally's classification, in a 1947 work he introduced the definition of frazeologičeskie edinicy 'phraseological units', within which it is possible to identify three subtypes based on the differing degrees of internal cohesion among the constituents.

Another classification of the fixed word combinations is provided by Mel'čuk (1998), who introduced the concept of phrasemes or set phrases, in opposition to that of free phrases (in English terminology). Intermediate between these two types are the semi-phrasemes or collocations; that is, partially opaque forms in which one of the components maintains its literal meaning while the other tends to be used metaphorically (for example, strong coffee).

Almost contemporaneously with the Soviet phraselogical school, the London linguistics school also showed an interest in word combinations. Firth (1957) introduced the notion of collocation to refer to the environment in which words occur.

More recently, Sinclair (1987) introduced, through the innovative lexicographical project COBUILD, an approach to the study of recurrent word-combinations based essentially on their frequency of use, thereby opening the way for the use of the corpus linguistic in phraseological studies (for a detailed reconstruction of these two main areas of phraseological studies, the Soviet and Anglo-Saxon ones, Cowie, 1998).

The corpus driven approach has extended the focus from phraseologisms to similar constructions such as collocations and high-frequent combinations of words, leading to the introduction of new concepts and the proliferation of new terminology: for example, the notion of lexical bundles (Biber et al., 1999), sequences of words occurring together with high frequency within the same register, known in the literature also by the name of clusters, chunks, or n-grams (Cheng, 2011).

Methodologically speaking, Stefanowitsch and Gries (2003) have introduced collostructional analysis, in which the methods of corpus linguistics are used to identify words statistically associated with a given construction and therefore the general meaning of the construction itself.

This broadened perspective in phraseological studies to take in collocations and the "preferential combinations" of words (on this latter concept Simone, 2006; 2007) has, on the one hand, encouraged the establishment of syntactical tests (of substitution, inversion, focalization, isolation, passivization, etc.) and of semantic criteria (noncompositionality, desemanticization of the constituents, capacity to designate conceptual units), allowing phraseologisms to be distinguished in a strict sense from similar constructions. Nevertheless, it has also demonstrated that the boundary between the two often remains difficult to determine.

In recent decades, especially in German and English linguistics, great attention has been paid to the comparison of set phrases across different languages.

Dobrovol'skij and Piirainen (2005) made an important theoretical contribution to the problem of cross linguistic comparability of idiomatic structures, by introducing the notion of "functional equivalence" to indicate equivalents that can be used in the same functional context in spite of the differences in their lexical structure.

Piirainen (2012) has continued along this line, giving rise to a research project called "Widespread Idioms in Europe and Beyond", which analyzes idioms that share the same lexical and semantic structure across a large number of European and extra-European languages.

The development of a cross-linguistic approach to phraseology has had important implications for translation studies and for research on Second Language Acquisition (SLA).

In a 2008 work Gries proposed a definition of phraselogism based on the co-occurrence of six different parameters (Gries, 2008: 2), beginning with the copresence of a lexical form and at least one other linguistic material of whatever kind, lexical or grammatical, without excluding the possibility of there being more than two elements (second criterion). Next comes the frequency of use and the non-obligatoriness of the adjacency of the constituents, a criterion strictly linked to the fifth one, which takes into consideration the greater or lesser syntactical flexibility. Finally, the sixth criterion, which is semantic and long held to be the most important, requires that phraseologism 
function as a semantic unicum, whether its meaning is compositional or not.

In this study and following on Gries (2008), the term "phraseologism" will be taken in the widest sense possible so as to include multi-word expressions of varying degrees of structural complexity (such as idiomatic expressions, proverbs, commonplaces, etc.) and with varying levels of structural and semantic cohesion (thus, not only fixed expressions in the strict sense but also structures which, irrespective of their degree of compositionality or idiomaticity, tend to be stored in the mental lexicon of the speaker as units).

Therefore, this approach is what has led us to include in the repertory of phraseologisms even mono-word formulaic expressions ${ }^{2}$, which is not in line with the first of the six criteria proposed by Gries, according to which a phraseologism must contain at least two lexical (or grammatical) elements.

The decision to consider mono-word formulas among the phraseologisms will be shown to be based on their idiosyncratic nature, which often does not permit one to predict their correct use from knowledge of the rules that govern the system of a language.

This consideration is also confirmed through interlinguistic comparison: an example could be from Italian or French, where the formulas for greetings, buongiorno! and bonjour! ${ }^{3}$, which represent lexicalizations deriving from the corresponding phrasal structures buon giorno and bon jour (literally 'good day'), correspond in Russian to the same non-univerbated form (dobryj den', literally 'good day'). In Spanish, on the other hand, the formula, though formed from the same lexical elements, uses the plural (buenos dias lit. 'good days'), while other languages use a construction that is functionally and structurally similar, which nevertheless involves a different noun than the one used in Italian or French (English good morning). In addition to the morphological-lexical component, it is the pragmaticfunctional one that represents the idiosyncratic element that undermines the ideal interlinguistic equivalence of such formulas: for example, to the pragmatic-function breadth of the Italian buongiorno there corresponds in English not so much the infrequent good day but, based on the communicative situation and the temporal factor, the choice between good morning, good afternoon or the generic hello. In German, too, the temporal factor plays a determining role in the morning greeting, between guten Tag and guten Morgen.

\footnotetext{
2 By formulas are meant those mono- or multi-word constructions represented in the first instance by expressions of courtesy (greetings, thank you, best wishes, apologies, invitations), but also, for example, by supplications or invectives.

${ }^{3}$ It should be noted that Italian dictionaries give as acceptable even non-univerbated forms, unlike French, where the synthetic form, already existing in the middle ages, is the only one possible.
}

These examples show that a simple greeting formula, which, moreover, a learner comes into contact with from his first exposure to the L2, can be formed from a monoword expression as well as a multi-word one, which we can easily classify, according to Gries, as a phraseologism. Nevertheless, whatever the structural composition of this formula, from a functional point of view we are dealing with what Krashen and Scarcella (1978) would define as a routine.

Therefore, given that our project for the creation of a multilingual resource of phraseologisms is first and foremost aimed at learners, there is no reason for not also including routines among the phraseological structures, especially considering that, as in the case of greeting formulas, they play specific pragmatic roles.

In this sense, of great use in selecting material to include in our database is the notion of construction as understood in $\mathrm{CxG}$ (see below): as a conventionalized association of a form and a function, either semantic or pragmatic. Starting from this approach, we can extend our definition of phraseologism to those lexically noncomplex constructions as well, which the learner acquires without having to analyze them and which serve specific communicative needs, exactly as in the case of interactional and greeting formulas.

\section{Construction Grammar and Phraseology}

$\mathrm{CxG}$ studies so-called constructions; that is, pairings of form and meaning ${ }^{4}$ which, according to Goldberg (2006: 5-6), can be of varying complexity (morphemes, words, syntactic patterns, etc.) and present differing degrees of abstraction/concreteness (for example, nonlexically specified syntactic patterns vs. fixed idiomatic expressions). As far as the aspect of creativity is concerned, Traugott and Trousdale (2013) introduced the concept of constructionalization, which is understood as the creation of a pairing with a new form and a new meaning, "in other words [...] the development of a new sign" (2013: 22).

\section{The Role of Construction Grammar in the Study of Phraseological Units}

$\mathrm{CxG}$ arose precisely from the need to find a theoretical model that was also adequate to describe phraseological-type units (Croft and Cruse, 2004: 225) whose form is difficult to predict (such as collocations) as well as its content (such as idiomatic expressions) and which present many descriptive difficulties for different grammatical models, thus leading them to be viewed as

\footnotetext{
${ }^{4}$ The concept of construction changes based on the different versions of $\mathrm{CxG}$. For an overall view of this see Croft and Cruse (2004: 257-290).
} 
marginal phenomena to be relegated to the lexicon. In $\mathrm{CxG}$, phraseologisms, thanks in part to the frequency with which they are recognized within the linguistic system, acquire importance and interest": "Newer research has emphasized the extent to which speech consists of formulaic or prefabricated phrases ('prefabs')" (Goldberg, 2013: 26). Nevertheless, studies in this area within a $\mathrm{CxG}$ framework have been relatively recent (Ziem and Lasch, 2013: 152), if the first writings of the founding fathers (Fillmore et al., 1988; Kay and Fillmore, 1999) are excluded. Fillmore et al. (1988) discussed the salient feature of this new theory in "Regularity and Idiomaticity in Grammatical Constructions: The Case of Let Alone", an article that can be considered the manifesto of the constructionist approach. In 1995, with Adele Goldberg's monograph, interest instead turned from phraseologisms to abstract argument structures, also considered as units of form and meaning. Nevertheless, according to Ziem and Lasch (2013: 152-153) it was only after Goldberg's wider definition of construction (2006) that the concepts and principles of $\mathrm{CxG}$ spread among European phraseologists as well and this because of the fact that Goldberg (1995: 4) considers construction as "a form-meaning pair" characterized by the criterion of non-compositionality. This definition does not include, however, the various types of phraseologisms, whose defining characteristic is not necessarily the non-predictability of the structure but rather the fact they have "at least one lexically specified element" (Gries, 2008: 10); Goldberg (2006: 5), on the other hand, considers constructions also as compositional structures if they occur with a certain frequency in a language, a necessary characteristic for the construction to be considered entrenched (Gries, 2008: 10; Ziem and Lasch, 2013: 153).

\section{Construction Based Analysis for Phraseological Units}

One of the fundamental characteristics of $\mathrm{CxG}$ is the interest in a holistic description of the analyzed structure, which provides information on both the formal aspect (phonological, morphological and syntactic description) and the semantic-pragmatic and discursive one (Croft, 2001: 18). Nevertheless, this type of analysis is also known to traditional phraseology: in fact, European phraseologists discovered early on that, for a correct use of phraseological units, it does not suffice to have only semantic knowledge, just as it is not enough to indicate the equivalent use in the L2; instead, also necessary is information of a pragmatic type,

\footnotetext{
${ }^{5}$ In particular, idiomatic expressions, not explainable (only) by means of a system of compositional rules, are, according to Stathi (2011: 149), prototypical constructions.
}

regarding the register of use, connotation, etc. (Mel'čuk, 1995; Mel'čuk, 2013; Mel'čuk et al., 1995; Polguère, 1995; Götz and Lorenz, 2002; Fried and Östman, 2004; Lambrecht, 2004; Dobrovol'skij, 2013). Indications of this type are highly useful particularly for teaching purposes.

Fillmore et al. (1988) have also demonstrated how important it is when describing a construction to take into account both its internal syntax (internal, idiosyncratic rules, such as its argument struc-ture) and its external ones (the syntactic context in which it is used). For example, Schafroth (2013) describes these two types of syntax for the Italian idiomatic expression Che cosa me lo chiedi a fare?, lit. 'What for are you asking me?' (which is an instantiation of the more abstract syntactic pattern [Che cosa Clitic

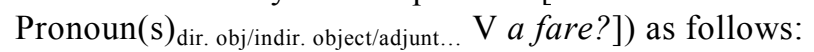

Internal Syntax:

obligatory arguments: subject (all persons, GEN. 2nd sing.), predicate (lexically open, objects often as pronouns), verb complement (a fare)

\begin{abstract}
External Syntax:
verb complements (according to the verb), e.g.: Cosa mi chiedi a fare come sto? Cosa mi chiedi a fare di uscire? Che cosa mi chiedi a fare che ne penso? [What for do you ask me how I am? What for do you ask me to go 'phraseme-constructions'out? What for do you ask me what I think of it?]
\end{abstract}

This clarifies that this type of construction is compatible, at the external syntax level, only with an objective subordinate which, in certain discursive contexts, can be nominalized within the phraseologism thanks to the anaphoric pronoun $l o$ [it].

\section{The Continuum between Lexicon and Syntax: The Role of Phraseme-Constructions}

Another important characteristic of the constructionist approach is that the phraseological sphere is not separated from the productive-type grammatical one; instead, the so-called continuum between lexicon and syntax is referred to, which, as shown below, allows the phraseologisms to be described more uniformly within the linguistic system, without relegating them to the lexicon.

This conception also has advantages in the teaching area (Mollica, 2015; Schafroth, 2015). It is thanks to this continuum between lexicon and syntax that the constructions and thus also phraseologisms, can present 
varying degrees of concreteness and/or abstraction. Fillmore et al. (1988: 505-506) speak of "substantive idioms" to indicate those idiomatic expressions (more or less) lexically specified and "formal idioms" for all those phraseologisms that present one or more syntactic slots not lexically specified and thus lexically open. This latter class is referred to in Croft and Cruse (2004: 234) as "schematic" and in Dobrovol'skij as "Phrasem-Konstruktionen" "phraseme-constructions" Dobrovol'skij, 2011: 114) ${ }^{7}$. Nevertheless, the slots cannot (always) be filled freely, since they must be logically and semantically compatible with the overall meaning of the construction. According to Fleischer (1997: 130ss.), these types of structures, precisely due to their partial schematic nature and resulting productivity $^{8}$, represent the interface between phraseology and syntax and as such have been neglected by phraseology for a long time (Feike, 2007: 66; Finkbeiner, 2008: 69).

A very productive example of formal/schematic idioms is the comparative correlative construction in German [je X desto/je/um so $\mathrm{Y}]$ :

Ger. Je mehr ich arbeite, desto/um so/je mehr verdiene ich. ('The more work the more money.')

Ger. Je schneller ich arbeite, desto/um so/je besser ist es. ('The faster I work, the better it is.')

The only lexically fixed parts of this schematic construction are the conjunctions je and desto/um so/ je. The conjunction je (lit. 'the more') introduces a secondary clause that indicates a premise whose consequence is explicitly stated in the main clause, which prototypically follows. According to Helbig and Buscha (1999: 461-462), the action expressed in the main clause occurs proportionally to that expressed in the secondary one. Moreover, both $\mathrm{X}$ and $\mathrm{Y}$ contain a comparative element (adjective or adverb). Even elliptical structures are possible, such as (3):

Ger. Je schneller, desto besser (lit. 'The faster, the better.')

\footnotetext{
${ }^{6}$ Here we shall use the term "phraseme-constructions" as in our view it best expresses the idea of the continuum existing between fixed phraseologisms (the object of study of phraseology) and the argument structure constructions (the object of study of syntax). On this topic, see below.

7 On the semantic-pragmatic potential of these constr $\mathrm{Cf}$. Finkbeiner (2008) on the productivity and relation between productivity and idiomaticity. uctions, see also Feike (2007).

Cf. Finkbeiner (2008) on the productivity and relation between productivity and idiomaticity.
}

Or idiomatic instantiations of the schematic construction $^{9}$ :

Ger. Je oller, je doller. (lit. 'the older, the crazier', idiom. 'there's no fox like an old fox.')

Since, as Croft and Cruse (2004: 234) comment, along the lines of Fillmore et al. (1988: 506): "The existence of the schematic idiom [...] does not preclude the existence of a substantive idiom"10 as in (4). This entails an idiomatic expression that can be paraphrased in the following manner: 'The older one is, the more one is crazy, extravagant, exuberant, energetic' (cf. http://redensarten-index.de/), which belongs to the colloquial register and is used mainly with a negative evaluation and an ironic connotation.

Along with the existence of schematic, partially lexically-filled constructions, $\mathrm{CxG}$ also postulates the existence of completely abstract constructions such as the so-called "argument structure constructions" (Goldberg, 1995), the most well-known example of which is the ditransitive construction, ${ }^{11}$ which has a formal schematic structure [V Subj Obj1 Obj2] associated with an abstract meaning ' $X$ CAUSES $Y$ TO RECEIVE Z' (Goldberg, 1995: 49). Even argument structure constructions can have fixed (phraseological) instantiations:

It. Anna ha dato a Giovanni del filo da torcere. (lit. 'Anne gave John some wire to twist.', idiom. 'Anna gave John a hard time'.)

The idiomatic instantiations of the ditransitive construction are thus characterized by the same semantics of transfer of the free instantiations; nevertheless, in the former the element in the direct object position is fixed from the lexical point of view.

The idiomatic expression is an example of "decoding idioms" (Fillmore et al., 1988: 504-505). In L2 learning it is precisely these that cause the most difficulty since, unlike "encoding idioms", the speaker/learner cannot deduce the meaning, based on his knowledge of the

\footnotetext{
9 Unlike free instantiations, the idiomatic ones in this construction do not appear to be very frequent in German.

${ }^{10}$ Very similar is the example in Fillmore et al. (1988: 506) on the "formal idiom" the X-er the Y-er, which can be idiomatically produced in the sentence: The bigger they come, the harder they fall.

${ }^{11}$ The term, originally coined in English linguistics to indicate transitive constructions with two direct objects (ed. Mary gave John a pen), was then extended to any construction "consisting of a (ditransitive) verb, an AGENT argument (A), a RECIPIENTlike argument (R), and a THEME argument (T)" (Haspelmath, 2007), independently of the way in which the various languages codify the two arguments, as long as the central idea of transfer is maintained (Goldberg, 1995: 141).
} 
language, if he has not already learned the construction $^{12}$ :

One of the reasons that a decoding idiom is a decoding idiom is because there are not any correspondences between the literal and idiomatic meaning of the parts of the decoding idiom. For example, kick the bucket is a transitive verb phrase, but its idiomatic meaning is the intransitive 'die,' and there is nothing that corresponds even metaphorically to a bucket (Croft and Cruse, 2004: 232).

The existence of both abstract and lexically specified constructions is explained, as noted above, by the conceptualization of the continuum between lexicon (and thus phraseology) and syntax. ${ }^{13}$ This approach to language opposes $\mathrm{CxG}$ to most of the projectionist theories, in particular Chomskian generativism, which provide for a clear separation between what is idiomatic in the language and what corresponds to productive rules. This is due to the fact that the phraseological units (completely or partially specified from the lexical point of view) are characterized internally by the occurrence of more or less fixed concrete lexemes, while the general syntactic rules call for the use of abstract categories (V and NP, etc.) (Croft and Cruse, 2004: 234). Stathi (2011: 150) describes the continuum between lexicon and syntax in the following manner:

The relation between grammar (that is, morphology and syntax) and lexicon is conceived of as a continuum in which the extremes are syntax (complex and schematic units), at one end and lexicon (concrete vs. atomic units and therefore words) at the other [authors' translation].

$\mathrm{CxG}$ thus rejects a clear-cut separation between syntactic and phraseological structures, since the latter are similar to both free phrases of a compositional type and to complex units of a morphological type; the boundaries between lexemes, phraseologisms and

\footnotetext{
${ }^{12}$ This is true also for another type of fixed construction, such as support verbs, whose learning typically represents a problem for learners. In this regard Deribas (1975) has proposed for Russian a concise dictionary of support verbs; see also in this regard Benigni and Cotta Ramusino (2015).

${ }^{13}$ See also Goldberg (2013) "Oftentimes utterances are at once novel and formulaic in that they involve constructions that dictate much of the lexical content, while filling open slots of the construction with new lexical content" (Goldberg, 2013: 26).
}

free phrases are thus not well defined (Stathi, 2011: 152; Benigni and Masini, 2010). In the specific case of ditransitive verbs, the phraseologisms are found inside the continuum between the verbs formed with their argument structure and the atomic morphological units (Stathi, 2011: 151). Stathi, referring to Croft and Cruse (2004), represent the continuum between syntax and lexicon as illustrated in Fig. 1 (cf. Stathi, 2011: 151; Croft and Cruse, 2004: 255).

As Fig. 2 illustrates, within this continuum the phraseme constructions are placed between the schematic/abstract constructions (such as the ditransitive construction [V Subj Obj1 Obj2]) and the phraseologisms specified from the lexical point of view, which in turn can be idiomatic instantiations of the schematic constructions (example: Maria mi ha dato del filo da torcere - literally: Maria gave to me some wire to twist.).

It thus emerges that both $\mathrm{CxG}$ and the phraseological studies share the same interest in the idiosyncratic elements of the linguistic system, that is, elements whose form, from the point of view of second language acquisition, the learner cannot predict from the meaning (collocations), or whose meaning is not predictable from the form (idioms). They nevertheless diverge regarding their terminology and perspective, as well as in the chosen objectives (cf. Gries, 2008: 10). Like phraseology, $\mathrm{CxG}$ entails a holistic analysis of the described construction; however, while the former limits its interest to the phraseological units (abstract argument constructions, for example, are not one of its objects of study) ${ }^{14}, \mathrm{CxG}$ sets as an objective describing the complete inventory of a language's constructions (cf. Goldberg, 1995): a speaker's knowledge of his language is, in fact, described by the construction, which includes the set of constructions in a language which are interconnected by links of varying nature.

In conclusion, the authors agree with Gries (2008: 10) when he writes:

From this, it of course also follows in turn that phraseological research has a lot to offer to these theories in terms of descriptive work as well as exploration of the ontological status of phraseological elements. In the opposite direction, phraseological research can benefit from the elaborate theoretical apparatus and the cognitively plausible background provided by Cognitive Grammar and Construction Grammar.

\footnotetext{
${ }^{14}$ In this regard it should be noted that Russian phraseological studies have for some time spoken of grammatičeskie frazeologizmy, also including in this comparative, concessive structures, etc. (Baranov and Dobrovol'skij, 2008: 75 ss).
} 


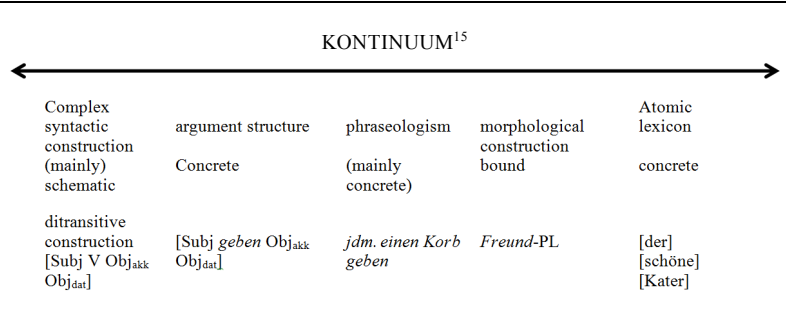

Fig. 1. The continuum between lexicon and syntax (in German) according to Stathi (2011)

\section{KONTINUUM}

$\begin{array}{lll}\longleftrightarrow \begin{array}{l}\text { schematic/abstract constructions } \\ \text { (schematic) }\end{array} & \begin{array}{l}\text { phraseme constructions } \\ \text { (partially schematic) }\end{array} & \begin{array}{l}\text { Phraseologisms } \\ \text { (lexically specified) }\end{array}\end{array}$

Fig. 2. Continuum between schematic/abstract constructions and phraseologisms

\section{"Electronic Multilingual Phraseology": The FRAME Project (FRAseologia Multilingue Elettronica)}

\section{About the FRAME Project}

This section will present the "multilingual phraseological" electronic resource ${ }^{16}$, whose main instrument is a database, conceived and organized within the framework of the $\mathrm{CxG}$ and from the point of view of the Italian learner of one of the considered L2, in order to provide a description of phraseologisms understood in the broad sense specified above.

We will present here the features and aims of the database we have created from a reflection on the problems that arise in the phraseological description, highlighting those aspects considered as innovative. ${ }^{17}$

We can imagine the database structure as composed of two levels: the first, termed the «entry field», representing an extension of the traditional structure of the definition of the lemma, which can be easily and quickly consulted and the second, the

\footnotetext{
15 Subj: subject, V: verb, Objakk, accusative complement, Objdat: Dative complement, $j d m$. einen Korb geben: 'Give a decisive no (lit. a basket) to someone', Freund-PL: 'friend-PL', [der]: '[the]', [schöne]: '[beautiful]', [Kater]: '[cat]'

${ }^{16}$ The "Multilingual Phraseology" project is financed by the University of Milan (2014, Line B financing) and calls for the participation of Italian and foreign universities. At present, in addition to the University of Milan, the University of Roma Tre and the Heinrich Heine University in Düsseldorf (Germany) have taken part.

17 The basic idea for the FRAME database goes back to Schafroth (dir.) (2014-).
}

«description field», completing the analysis of the unit in a detailed way, describing it precisely based on the various linguistic levels (morphological, syntactic, semantic-pragmatic and discursive) (Croft, 2001). A holistic description of the phraseologism is thus obtained which has clear validity not only in the lexicographical field but also (and above all) in the didactic one (see above).

\section{The Database: A Description}

The languages for which a phraseological description is contemplated are: Chinese, French, Japanese, English, Italian, Russian, Spanish and German. The meta-language of the database is Italian; therefore all the explicative parts of the database (see below) are written in Italian, since the "ideal" learner we address is an Italian student, whose level ranges from A1 to $\mathrm{C} 2$. Because of the wide linguistic spectrum taken into analysis in the database, the resource is already provided with the option for translating all the entries into the language of interest (the French unit will be explained in French, the Russian one in Russian and so forth).

\section{The Entry Field}

The "phraseologism field" contains the following sub-fields:

- The "phraseologism text" field, which contains the phraseologism text and relative audio file for the language consulted. ${ }^{18}$

- "Transcription" and "transliteration" fields for those languages whose alphabets differ from the Latin one.

- "Variant" field. Where these exist, they contain the variants of the phraseologism; by variant is meant minimum variations (lexical, morphological, syntactic) of form. For example, for the Italian dare del filo da torcere 'give some wire to twist' there is the variant dare filo $d a$ torcere, without the partitive article; or for tenere il piede in due scarpe (lit. 'keep the foot in two shoes'; idiomatic: 'keep a foot in both camps'), the form with lexical variant tenere il piede in due staffe (lit. 'keep the foot in two stirrups'); even for the Italian buongiorno 'good morning', there exists the lexical variant buondi.

\footnotetext{
${ }^{18}$ As regards the phraseme constructions typology, this first field will contain the abstract structure, partially specified at the lexical level, with the indication of the lexically nondetermined slot.
} 
On the level of morphological variation, the Russian dobroe utro (lit. 'good morning') has the variant dobroe utrečko (produced using evaluative morphology), while on the level of syntactic variation the variant $s$ dobrym utrom (lit. 'with good morning' (using the preposition $s$ 'with', determined by the argument structure of the implied verb pozdravljat' 'to wish').

Moreover, the variants are arranged along the diastratic, diatopic and diaphasic axes presented in a predefined menu with the following options: standard, colloquial, vulgar, regional, solemn, archaic and youthful (jargon).

"Literal translation" field, which contains the translation from the L2 into Italian, which represents, as we have said, the language of reference for each of the L2 considered. The literal translation allows the lexical constituents and mental images behind the process of construction of meaning (which can vary from one language to another) to be explained also for initial learners of the L2.

"Equivalent" field. Phraseology normally distinguishes among: (a) full equivalents, (b) partial equivalents, (c) phraseological parallels and (d) nonequivalents (Dobrovol'skij, 2013: 212-213). This field, notoriously difficult to compile, is compensated by the "literal translation" field, which becomes necessary when the target language has available only a functionally equivalent phraseologism (c) or no equivalent at all (d).

Nevertheless, in light of an overall view of the systemic correspondence between the two languages (Dobrovol'skij, 2013: 214) and considering the fact that even the type (a) equivalent will reveal a series of syntactic, pragmatic and functional differences with respect to the starting language (which the available lexicographical resources cannot completely describe), it was thought necessary to fill in this gap in the second level of the database.

To demonstrate the necessity for the two fields of "literal translation" and "equivalent", one need only consider the gap between the literal translation and what is rendered by the equivalent field that emerges from an analysis of the formulas described above, constructions wrongly held to be easy for learners. As previously noted, the formulas represent a fundamental component of linguistic competence but are often ignored by traditional lexicography ${ }^{19}$. If we consider another example of a formula in light of the

\footnotetext{
19 The formulas, in particular the multi-word ones, are not presented as single entries in traditional monolingual dictionaries, where they are confined to the "idiomatic expression" section of the individual lemmas (for example, the German Guten Tag appears among the fixed phrases of the Tag lemma, and often not even in the first position), or even in phraseological dictionaries to our knowledge.
}

database structure, we can see that to the Italian ciao (lit. 'hello/hi'), which represents informal greeting or leave-taking between two or more person, there corresponds in Russian, for example, on the pragmatic-functional level, both privet, in the case of a meeting and poka, in the case of a leave-taking formula. These further and important distinctions are examined in the second level of the description.

Therefore, the equivalent offers a concise answer that is quick to consult for the user, while the complete description of the phraseologism helps the learner to understand the specificities of the language of study, above all the pragmatic ones.

"Type of phraseologism" field: this field defines the type of phraseologism, which can be an idiomatic expression, a schematic idiom/phraseme construction (the most productive of all the types of fixed constructions, a proverb, a collocation, or a "formula").

"Formality" field. This field is arranged on two levels: the first contains the various degrees of "formality" (very formal, formal, neutral, informal, very informal), which are then further specified on the second level with traditional style annotations (very formal corresponds to solemn, informal to youthful, jargon, etc.). This two-level structure appears useful for the constructions analyzed in the present database: If, in fact, the degree of formality is particularly important for the formulas, this aspect of parameter is not sufficient to describe the idiomatic expressions, for which what is traditionally referred to as register is more relevant (in its various forms based on the system of reference). ${ }^{20}$

"Transmission channel" field, where the transmission channel can be oral, written, or both.

"Meanings-paraphrases" field, which contains the meanings of the phraseologism from at least two monolingual dictionaries.

"Examples taken from the corpora" field, which contains the contexts of use regarding various meanings of the phraseological units, useful in exemplifying meanings and making them less ambiguous. For this section we will use, if available, the most representative corpora of each language.

\footnotetext{
${ }^{20}$ Moreover, the term register is quite polysemic; one finds different definitions and classifications of it (see http://www.treccani.it/enciclopedia/registro_\%28Enciclopediadell\%27Italiano\%29/). For Italian alone, for example, Gobber/ Morani (2010: 205) distinguish 4 registers (solemn, formal, average, colloquial); others, such as Dardano (2005) 8 (solemn, cultured, formal, average, colloquial, informal, popular, familiar). Berruto (1987) introduces a degree of formality and the relationship between the speakers as discriminating elements of register. In this paper, the attempt is made to join this sociolinguistic approach, more sensible to the pragmatic aspect, to that of register, in the traditional sense.
} 
"Thesaurus" field, which contains the synonyms for the analyzed construction, which is represented by individual lexemes, less frequently by phraseologisms. For the Italian dare filo da torcere (lit. 'give wire to twist', equivalent, 'to present real difficulties'), for example, there is the synonymous lexeme ostacolare 'to hinder'. At the phraseological level we can instead establish a partial correspondence in meaning with the construction mettere $i$ bastoni tra le ruote (lit. 'put sticks between the wheels', idiomatic, 'put a spanner in the works'). Obviously the correspondence in meaning/function between the two phraseologisms cannot be total since, based on the principle of No Synonymy (Goldberg, 1995: 67), a difference in function/meaning always corresponds to a difference in form.

"Collocations" field, which contains all the collocations in which the analyzed phraseological unit appears (dire buongiorno, lit. 'to say good day', augurare il buongiorno, lit. 'to wish a good day').

\section{The Description Field}

The second level of the database, the most innovative component of the project, describes the phraseological constructions at the semantic, syntactic, morphological, lexical, pragmatic and discursive levels, offering a thorough list of instruments for understanding the phraseological units and their use in context. This type of holistic description is explicitly based on Croft's descriptive model (2001).

There are three fields in the semantic description:

- Representation of the argument structure through the actants $(\mathrm{X}, \mathrm{Y}, \mathrm{Z})$, completed by the analysis of their fundamental semantic features: in the case of dare filo da torcere this would be " $\mathrm{X}$ creates difficulties for $\mathrm{Y}$, where $\mathrm{X}[ \pm$ animated $]$ and $\mathrm{Y}$ [prevalently animated]"

- The determination of the semantic field to which the structure belongs based on the proposal of Bárdosi et al. (2003), according to the onomasiological approach characterizing the database structure, which includes 25 semantic fields, each of which divided in turn into subfields. However, slight modifications of this classification cannot be excluded if these are deemed necessary during work on the project

- Evaluation/connotation field, divided into positive evaluation (approval, admiration, flattery), negative evaluation (disapproval, sarcasm, disdain) and neutral evaluation, which records the intrinsic connotation of the phraseologism; a phraseological unit can have an intrinsically positive evaluation, for example, the compliment sei un genio! (lit. 'you're a genius'). Such an evaluation can nevertheless be overturned by the illocutionary intention of the speaker, who can transform it, thanks in part to prosodic and intonation elements. The same is true for the formulas. The "pragmatic" field (see below) takes into account the possible difference between evaluation/connotation and illocutionary force expressed by the speaker

The syntactic description includes the following fields:

- The obligatory elements of the construction (in the case of the Italian dare filo da torcere, these are: the two actants $\mathrm{X}$ and $\mathrm{Y}$, the verbal form dare, its direct object filo da torcere) and the optional ones (here, del)

- The possible syntactic transformations, which represent a very important factor for L2 learners and a frequent cause of major errors. In the case of nominal phraseologisms, the main transformations entail the possibility of modifying the noun, or separating it from its modifier; and in the case of verbal phraseologisms, the possibility of transforming the diathesis of the verb (active, passive, reflexive). Obviously the syntactic transformations are language-specific as well as idiosyncratic to a large extent and they depend on the classes of words and codified grammatical categories of each language

The morphological description is made up of a single field that describes the features of the words composing the unit. For dare filo da torcere, it is necessary to indicate that the verb can be found in all moods, tenses and voices and that filo da torcere is to be considered as an indivisible unit. Moreover, for the inflectional languages annotations for specific cases may appear; more generally, the processes of derivation and composition may be indicated and in those languages that grammaticalize the aspect category, it may be necessary to state whether the verb can occur in both aspects.

The pragmatic description is perhaps the most detailed one. Here the parameters of analysis relevant for all the languages included in the project are investigated, in order to reflect all the variables of use. Specifically, the following fields are particularly relevant:

- Recipient (one or more persons)

- Relationship among the speaker (close, distant, mixed), as in the case of the Italian greeting salve! (lit. 'hello!'), which permits the speaker to avoid choosing between the direct form of address $t u$ 
(second person singular) and the formal one lei (which in Italian is formed by the third person feminine singular)

- Hierarchy, a particularly significant field for Oriental languages (relations that call for two opposite poles, high and low, with vectors in both directions and equality), which are strictly codified above all in the area of formulas of courtesy

- Speech acts; this section specifies which speech act (leave-taking expression, imploring, etc.) is produced by the phraseological construction being analyzed, irrespective of the intrinsic semantic connotation, thanks to the illocutionary force of the speaker, the context and the discursive situation. This field is currently present in only a few multimedia lexicographical resources, such as the Nacional'nyj Korpus Russkogo Jazyka (NKRJa, n.d.), where such tagging exists and can be an aid for users, who can carry out extensive research regarding a certain speech act

Discursive features: this field analyzes the role of discourse markers which phraseologism can acquire from a series of factors, mainly: context and intonation. For example, the Italian buonanotte! 'good night', in addition to, or precisely due to the fact that it constitutes a leave-taking expression, can appear as an ironic closure of discourse when accompanied by a particular intonation. The same is true for the Italian sei un genio! 'you are a genius', which, when it involves a specific intonation and context, takes on an ironic or sarcastic meaning, overturning the originally positive connotation. Similarly, the Italian construction va a quel paese (lit. 'go to that country', idiomatic: 'go to Hell') becomes, in addition to its clearly performative role, a means of signaling the end of a speaking turn at a discursive level.

Historical-cultural peculiarity; where possible the learner can be given an explanation for a certain image or metaphor behind the phraseologism. For example, in the case of the above-mentioned dare filo da torcere, it can be interesting to go back to the etymology of the form, which brings to mind the tiring activity of twisting a wire. This information allows the learner to see in the synchronic structure $\mathrm{V}$ + Theme (= dare + filo da torcere $)$ an original structure $\mathrm{V}+$ Theme + Goal $(=$ dare + filo $+d a$ torcere) which has by now become completely opaque. Another example is the Spanish expression $a$ buenas horas mangas verdes (lit. 'At the right hour green sleeves'), which is used to comment on or take someone to task for being late. Behind this image is the outfit, a vest from which the green shirt sleeves of a medieval Spanish policeman, the Santa Hermandad, noted for the slowness of his interventions, protrude.
The concomitant prosodic and gestural features (where possible with links to audiovisual material) complete the description.

The identification of the above parameters turned out to be particularly complex, above all due to the highly typologically diverse nature of the language samples analyzed (which included analytic, synthetic and isolating languages). Even apparently simple cases, such as the Italian buongiorno, turned out to be rich in nuance.

As explained above, we are implementing the database starting from the onomasiological principle: we work on the different semantic fields, looking for the most representative phraseological units of a given field in each language; analogies and differences will result from a comparative query. Therefore, the aim is not to find equivalents in a "target" language, but to describe thoroughly the phraseological units. Italian, as already stated, is at this stage of the project the metalanguage, used in the description of the phraseologisms of all languages (included the Italian ones as well). In any event, we plan before long to provide the description in each considered language. The initial concepts on which we are working at the moment are 'greetings' and 'pleasures of the table' and at present we have about 50 units described. To complete the first step of the project, we plan to take about 10-15 phraseological units for each semantic field.

\section{Conclusion}

The FRAME project has been created to pursue new approaches in phraseology. These require first of all a broad definition of phraseologism (primarily understood as semantic unit), which takes into account the fact that, from a cross-linguistic point of view, a given concept may be expressed in one language by a multi-word expression, while in another one by a mono-word signifiant. This view, surprising at first sight, fits very well with our methodological focus: the framework of Construction Grammar. It allows us to understand that entrenched and/or non-compositional expressions are constructions in the sense of form-meaning pairings, which have to be treated as a whole. This means, according to one of the fundamental claims of $\mathrm{CxG}$, that constructions have to be described holistically, comprising all aspects of their form and meaning. Whereas phraseologisms are usually treated in dictionaries with a minimum of lexicographical complexity (providing at best a general meaning completely abstracted from the specific linguistic context), the FRAME database sets itself the task of gathering as much linguistic information as necessary for the users to understand and even use idioms, formulas and schematic constructions in their language 
of choice. In this way, phonological, morphological and syntactic properties, as well as semantic, pragmatic and even discourse functional characteristics can be registered-and consulted.

The description of these particularities proceeds in two stages: firstly, from an onomasiological perspective, starting from a basic concept, which is part of a semantic field or reflects a specific expressive intention (the illocutionary force of a speech act) and then assigning relevant properties to predefined categories, such as the degree of formality, hierarchical constraints, evaluative parameters, specificity in register, style or the communication channel (oral and written). Secondly, within the linguistic profile of a chosen concrete phraseologism, further properties and additional information can be found (e.g., specific notes on syntactic or pragmatic features, links to video and audio files, corpus examples). Another innovative approach will be introduced at a later stage of the project: the level-specific classification of phraseologisms according to the European Reference Framework.

Through the interaction of these criteria users will be able to search phraseological forms (in any of the eight languages) that correspond to the conceptual profile they themselves have selected. The result might be finding a form (a phraseologism) in one language whereas for another language the selected conceptual profile may achieve no result. If a user wants to search a greeting formula in FRAME showing the characteristics of politeness, a neutral register, the fact of being addressed to familiar or unfamiliar people and of being used by someone who is just about to enter another person's home, this will probably lead to only one result in only one language: The Italian permesso? (lit. 'allowed?'). Thus, even negative results might help us to understand the specificity of phraseologisms as pairings of form and meaning.

\section{Acknowledgement}

The authors would like to thank Prof. Dr. María Isabel González Rey, Universidade de Santiago de Compostela, for her contribution in editing and proof reading this manuscript. Special thanks are also due to the journal reviewers for their constructive comments and suggestions on an earlier version of this paper.

\section{Authors' Contributions}

The article is the result of the close collaboration of four authors; however, for academic purposes only:

Valentina Benigni: Responsible for "Phraseological Studies: State of the Art", "Construction Based Analysis for Phraseological Units" and "About the FRAME Project".
Paola Cotta Ramusino: Responsible for "The Database: A Description", "The Entry Field" and "The Description Field".

Fabio Mollica: Responsible for the first paragraph after the heading of "Construction Grammar and Phraseology", "The Role of Construction Grammar in the Study of Phraseological Units" and "The Continuum between Lexicon And Syntax: The Role of PhrasemeConstructions".

EImar Schafroth: Responsible for the "Introduction" and the "Conclusion".

\section{Ethics}

This article is original and contains unpublished material. The corresponding author confirms that all of the other authors have read and approved the manuscript and no ethical issues involved.

\section{References}

Bally, C., 1951. Traité de Stylistique Française. 3rd Edn., Librairie Georg and Cie, Genève, Librairie Klinksieck, Paris, pp: 331.

Baranov, A.N. and D.O. Dobrovol'skij, 2008. Aspekty Teorii Frazeologii. 1st Edn., Znak, Moskva, ISBN-10: 5955102353, pp: 656.

Bárdosi, V., S. Ettinger and C. Stölting, 2003. Redewendungen Französisch/Deutsch: Thematisches Wörter- und Übungsbuch. 3rd Edn., Francke, Tübingen, ISBN-10: 3825217035, pp: 259.

Benigni, V. and P. Cotta Ramusino, 2015. La struttura Argomentale Dei Verbi Supporto in Russo: Un Approccio Data-Driven. In: Il Ruolo Della Grammatica Valenziale Nell'insegnamento Delle Lingue Straniere, Bianco, M.T., M.M. Brambilla and F. Mollica (Eds.), Aracne, Roma.

Benigni, V. and F. Masini, 2010. Nomi sintagmatici in russo. Studi Slavistici, 7: 145-172.

DOI: 10.13128/Studi_Slavis-9203

Berruto, G., 1987. Sociolinguistica Dell'italiano Contemporaneo. 1st Edn., La Nuova Italia Scientifica, Roma, ISBN-10: 8843063499, pp: 218.

Biber, D., S. Johansson, G. Leech, S. Conrad and E. Finegan, 1999. Grammar of Spoken and Written English. 1st Edn., Longman, Harlow, ISBN-10: 9780582237254, pp: 1204.

Burger, H., 2010. Phraseologie: Eine Einführung am Beispiel des Deutschen. 4th Edn. Schmidt, Berlin, ISBN-10: 3503061703, pp: 224.

Cheng, W., 2011. Exploring Corpus Linguistics: Language in Action. 1st Edn., Routledge, New York, ISBN-10: 978-0415585477, pp: 288.

Cowie, A.P., 1998. Phraseology. Theory, Analysis and Applications. 1st Edn., Oxford University Press, Oxford, ISBN: 9780198294252, pp: 272. 
Croft, W., 2001. Radical Construction Grammar: Syntactic Theory in Typological Perspective. 1st Edn., Oxford University Press, Oxford, ISBN-10: 0198299540 , pp: 416.

Croft, W., 2005. Logical and Typological Arguments for Radical Construction Grammar. In: Construction Grammars: Cognitive Grounding and Theoretical Extensions, Östman, J.Ö. and M. Fried (Eds.), John Benjamins, Amsterdam and Philadelphia, ISBN-10: 9789027218230, pp: 273-314.

Croft, W. and A.D. Cruse, 2004. Cognitive Linguistics. 1st Edn., Cambridge University Press, Cambridge, ISBN-10: 978-0521667708, pp: 372.

Dardano, M., 2005. Nuovo Manualetto di Linguistica. 1st Edn., Zanichelli, Bologna, ISBN-10: 9788808176349, pp: 320.

Deribas, V.M., 1975. Ustojčivye Glagol'no-Imennye Slovosočetanija Russkogo Jazyka. 1st Edn., Russkij Jazyk, Moskva, pp: 256.

Dobrovol'skij, D., 2011. Phraseologie und Konstruktionsgrammatik. In: Konstruktionsgrammatik III: Aktuelle Fragen und Lösungsansätze, Lasch, A. and A. Ziem (Eds.), Stauffenburg, Tübingen, ISBN-10: 978-3-86057-196-5, pp: 110-130.

Dobrovol'skij, D., 2013. German-Russian idioms online: On a new corpus-based dictionary. Proceedings of the Annual International Conference "Dialogue", (ICD' 13), pp: 210-217.

Dobrovol'skij, D. and E. Piirainen, 2005. Figurative Language: Cross-cultural and Cross-linguistic Perspectives. 1st Edn., Elsevier Ltd., Amsterdam, ISBN-10: 0080438709, pp: 419.

Donalies, E., 2009. Basiswissen Deutsche Phraseologie. 1st Edn., UTB, Tübingen and Basel, ISBN-10: 3825231933, pp: 132.

Feike, H., 2007. Syntaktische Aspekte der Phraseologie III: Construction Grammar und Verwandte Ansätze. In: Phraseologie: Ein internationals Handbuch der Zeitgenössischen Forschung, Burger, H. (Ed.), de Gruyter, Berlin, ISBN-10: 3110190761, pp: 63-76.

Fillmore, C.J., P. Kay and M.C. O'Connor, 1988. Regularity and idiomaticity in grammatical constructions: The case of let alone. Language, 64: 501-538. DOI: $10.2307 / 414531$

Finkbeiner, R., 2008. Idiomatische Sätze im Deutschen: Syntaktische, Semantische und Pragmatische Studien und Untersuchung ihrer Produktivität. 1st Edn., Acta Universitatis Stockholmiensis, Stockholm, ISBN-10: 9185445959, pp: 294.

Firth, J.R., 1957. Modes of Meanings. 1st Edn., Oxford University Press, London, pp: 190-215.

Fleischer, W., 1997. Phraseologie der deutschen Gegenwartssprache. 1st Edn., Tübingen: Niemeyer, pp: 299. ISBN: 3484730323.
Fried, M. and J.O. Östman, 2004. Construction Grammar: A Thumbnail Sketch. In: Construction Grammar in a Cross-Language Perspective, Fried, M. and J.O. Östman (Eds.), John Benjamins, Amsterdam and Philadelphia, ISBN-10: 9789027218223, pp: 11-86.

Gobber, G. and M. Morani, 2010. Linguistica Generale. 1st Edn., McGraw Hill Italia, Milano, ISBN-10: 9788838664939, pp: 304.

Goldberg, A.E., 1995. Constructions: A Construction Grammar Approach to Argument Structure. 1st Edn., University of Chicago Press, London and Chicago, ISBN-10: 9780226300863, pp: 265.

Goldberg, A.E., 2006. Constructions at Work: The Nature of Generalization in Language. 1st Edn., Oxford University Press, Oxford, ISBN-10: 9780199268511, pp: 299.

Goldberg, A.E., 2013. Constructionist Approaches. In: The Oxford Handbook of Construction Grammar, Hoffmann, T. and G. Trousdale (Eds.), Oxford University Press, Oxford, ISBN: 978-0-19-539668-3.

Götz, D. and G. Lorenz, 2002. Englische Idioms von AZ. 1st Edn., Hueber, München, ISBN-10: 3907194039, pp: 512.

Gries, S.T., 2008. Phraseology and Linguistic Theory: A Brief Survey. In: Phraseology: An interdisciplinary perspective, Granger, S. and F. Meunier (Eds.), John Benjamins, Amsterdam and Philadelphia, ISBN-10: 9789027232465, pp: 3-25.

Haspelmath, M., 2007. Ditransitive Alignment Splits and Inverse Alignment. 1st Edn., Functions of Language 14.1, ISSN-10: 0929-998X, pp: 102.

Hausmann, F.J., 1997. Tout est Idiomatique Dans Les Langues. In: La Locution Entre Langue et Usages, Martins-Baltar, M. (Ed.), ENS Éditions, Fontenay, St Cloud, ISBN-10: 2902126433, pp: 277-290.

Helbig, G. and J. Buscha, 1999. Deutsche Grammatik: Ein Handbuch für den Ausländerunterricht. 18th Edn., Langenscheidt, Leipzig, ISBN-10: 3324001188, pp: 736.

Kay, P. and C.J. Fillmore, 1999. Grammatical constructions and linguistic generalizations: Thewhat's X doing Y? Construction. Language, 75: 1-33. DOI: $10.2307 / 417472$

Krashen, S. and R. Scarcella, 1978. On routines and patterns in language acquisition and performance. Lang. Learn., 28: 283-300. DOI: 10.1111/j.14671770.1978.tb00135.x

Lambrecht, K., 2004. On the Interaction of Information Structure and Formal Structure in Constructions: The Case of French Right-Detached Comme-N. In: Construction Grammar in a Cross-Language Perspective, Fried, M. and J.O. Östman (Eds.), John Benjamins, Philadelphia, ISBN-10: 9789027218223, pp: 157-199. 
Makkai, A., 1972. Idiom Structure in English. 1st Edn., Mouton, The Hague, ISBN-10: 9027921059, pp: 380.

Mel'čuk, I., 1995. Phrasemes in Language and Phraseology in Linguistics. In: Idioms: Structural and Psychological Perspectives, Everaert, M., E.J. van der Linden, A. Schenk and R. Schreuder (Eds.), Hillsdale, Lawrence Erlbaum Associates, N.J.-Hove, ISBN-13: 978-0805815054, pp: 167-232.

Mel'čuk, I., 1998. Collocations and Lexical Functions. In: Phraseology: Theory, Analysis and Applications, Cowie, A.P. (Ed.), Oxford University Press, Oxford, ISBN-13: 9780198294252, pp: 23-53.

Mel‘čuk, I., 2013. Tout ce que nous voulions savoir sur les phrasèmes, mais... Cahiers de Lexicologie: Revue Internationale de Lexiciologie et Lexicographie, 102: 129-149.

Mel'čuk, I., A. Clas and A. Polguère, 1995. Introduction à la Lexicologie Explicative et Combinatoire. 1st Edn., Duculot, Louvaine-la-Neuve, ISBN-10: 2801111066, pp: 256.

Mollica, F., 2015. Die Rolle der Kontrastivität in der Phraseodidaktik: Eine kognitive und konstruktionsgrammatische Perspektive. In: Deutsch Kontrastiv Aus Italienischer Sicht: Phraseologie, Temporalität und Mehr, Di Meola, C. and D. Puato (Eds.), Lang, Frankfurt am Main, ISBN-10: 978-3-631-65452-1, pp: 13-35.

NKRJa, n.d. Nacional'nyj Korpus Russkogo Jazyka.

Piirainen, E., 2012. Widespread Idioms in Europe and Beyond: Toward a Lexicon of Common Figurative Units. 1st Edn., Lang, New York, ISBN-10: 9781433105791, pp: 591.

Schafroth, E., 2013. How constructions should be dealt with in learner's lexicography-illustrated for the Italian language. Proceedings of the International Conference "Constructionist Approaches to Language Pedagogy", Nov. 8-9, University SaintLouis, Brussels.

Schafroth, E. (dir.), 2014. Piattaforma per chi impara l'italiano. Institut für Romanistik, Universität Düsseldorf.
Schafroth, E., 2015. Italian phrasemes as constructions: How to understand and use them.

Simone, R., 2006. Classi di Costruzioni. In: Zhì. Scritti in Onore di Emanuele Banfi in Occasione Del Suo $60^{\circ}$ Compleanno, Grandi, N. and G. Iannàccaro (Eds.), Caissa, Cesena and Roma, ISBN-10: 9788888756349, pp: 383-409.

Simone, R., 2007. Constructions and Categories in Verbal and Signed Languages. In: Verbal and Signed Languages. Comparing Structures, Constructs and Methodologies, Pizzuto, E., P. Pietrandrea and R. Simone (Eds.), Mouton, Berlin and New York, ISBN-10: 9783110195859, pp: 198-252.

Sinclair, J.M., 1987. Collocation: A Progress Report. In: Language Topics: Essays in Honour of Michael Halliday. Steele, R. and T. Threadgold (Eds.), John Benjamins, Amsterdam, pp: 319-331.

Stathi, K., 2011. Idiome und Konstruktionsgrammatik: Im Spannungsfeld zwischen Lexikon und Grammatik. In: Konstruktionsgrammatik III: Aktuelle Fragen und Lösungsansätze, Lasch, A. and A. Ziem (Eds.), Stauffenburg, Tübingen, ISBN-10: 3860571966, pp: 149-163.

Stefanowitsch, A. and S.T. Gries, 2003. Collostructions: Investigating the interaction between words and constructions. Int. J. Corpus Linguist., 8: 209-43.

Traugott, E.C. and G. Trousdale, 2013. Constructionalization and Constructional Changes. 1st Edn., Oxford University Press, Oxford, ISBN-10: 978-0-19-967989-8, pp: 304.

Vinogradov, V.V., 1947. Ob Osnovnyx Typax Frazeologičeskix Edinic v Russkom Jazyke. In: Sbornik statej i materialov, Obnorskij, S.P. (Ed.), Akademija Nauk, Moskva, pp: 339-364.

Ziem, A. and A. Lasch, 2013. Konstruktionsgrammatik: Konzepte und Grundlagen gebrauchsbasierter Ansätze. 1st Edn., de Gruyter, Berlin, ISBN-10: 3110272946, pp: 232. 